\section{Evaluating the Reaction of Peach Cultivars to Infection by Three Botryosphaeria Species}

\author{
K.O. Britton ${ }^{1}$ and F.F. Hendrix \\ Department of Plant Pathology, University of Georgia, Athens, \\ GA 30602
}

\author{
P.L. Pusey, W.R. Okie, and C.C. Reilly \\ Agricultural Research Service; U.S. Department of Agriculture, Byron, \\ GA 31008
}

\section{J.W. Daniell \\ Department of Horticulture, University of Georgia Experiment Station, Experiment, GA 30212}

Additional index words. host vigor, disease assessment, peach tree fungal gummosis, canker, gummosis, Prunus persica

Abstract. Two field experiments were conducted to assess peach (Prurus persica L.) cultivar susceptibility to the three Botryosphaeria spp. that cause peach tree fungal gummosis. Inoculated trees were evaluated for disease severity by rating gum exudation, vascular discoloration, and fungal colonization. Each severity measurement yielded a different rank ordering of cultivars for susceptibility. However, in a greenhouse study, these same measurements gave consistent rankings for aggressiveness of the fungal species on 'Blake'. Despite large differences in disease severity in the greenhouse study, none of the severity measures were correlated with tree growth after inoculation. The only factor significantly correlated with growth rate of the trees after inoculation was growth rate before inoculation.

Peach tree fungal gummosis (PTFG) first appeared in central Georgia in the early 1970 s (Weaver, 1974). The disease has spread rapidly from the vicinity of Fort Valley, Ga., and is now present from Louisiana to North Carolina, including northern Florida (Reilly and Okie, 1982). Copious gum exudation on trunks and scaffold limbs is the first external symptom. Inner bark and outer xylem and cambial layers beneath the gum become necrotic. Cankers become slightly swollen by exfoliated, diseased cortical tissue that adheres to the tree with dried gum and fungal mycelium (Britton and Hendrix, 1984). Lack of definite margins on cankers precludes direct measurement of canker length or area and, therefore, greatly complicates disease severity comparisons and cultivar susceptibility evaluations. The economic consequences of PTFG are presently unknown. Most trees in the disease area become infected by the 3rd year after planting.

When inoculum of the fungi that cause PTFG [Botryosphaeria dothidea (Moug. ex Fr.) Ces \& de Not., B. obtusa (Schw.) Shoemaker or B. rhodrina (Berk \& Curt. apud Cke. v. Arx)] is, introduced to the wound,

Received for publication 25 July 1988. The cost of publishing was paid by the Univ. of Georgia Agricultural Experiment Station. The cost of publishing this paper was defrayed in part by the payment of page charges. Under postal regulations, this paper therefore must be hereby marked $a d$ vertisement solely to indicate this fact.

'Present address: USDA Forest Service, Carlton St., Athens, GA 30602. taken 9 weeks after inoculation confirmed the rank order of cultivars established by rating the gumming induced by natural infections. The fungus, however, could be reisolated from all cultivars and selections. The gum reaction, therefore, was not credited with the exclusion of the pathogen.

Willison (1932) showed that gum constituted an effective barrier to invasion of peach trees by Sclerotinia, but not against Cytospora. The experiments reported here were designed to evaluate the use of gum ratings, vascular discoloration, and fungal invasion as measures of disease severity for cultivar comparisons.

Comparison of cultivars in field: field inoculation (Expt. 1). Gum ratings, vascular discoloration, and fungal re-isolation frequency were compared for 'Harbrite', 'Harken', and 'Winblo' in a 10-year-old Fort Valley, Ga., orchard. In Oct. 1982, 12 trees of each cultivar were randomly selected and each tree divided into quadrants. Inoculation with B. dothidea, B. obtusa, B. rhodina, or a control treatment was randomly imposed on the quadrants of each tree. For each quadrant, ten 1-year-old twigs (diameter $<1 \mathrm{~cm}$ ) were cut with a scalpel to the xylem, $\approx 20$ $\mathrm{cm}$ from the shoot apex. A plug of fungal mycelium cut from 10-day-old cultures growing on acidified potato dextrose agar (APDA) was inserted beneath the resulting 2-cm bark flap. Control wounds received sterile APDA. All wounds were then wrapped for 8 months with adhesive tape. Twigs were removed from the trees in June 1983 and cut into serial sections $2.5 \mathrm{~cm}$ long. Each segment was first inspected for the presence of vascular discoloration. Discoloration data for the segments of each twig were compiled to determine the extent of vascular discoloration above and below the inoculation point. Each segment was surface-sterilized in $0.5 \%$ sodium hypochlorite in $10 \%$ ethanol, plated on APDA, and incubated 2 weeks under fluorescent lights $\left(45 \mu \mathrm{mol} \cdot \mathrm{s}^{-1} \cdot \mathrm{m}^{-2}\right)$ at $24 \mathrm{C}$ to determine whether fungal invasion had occurred. Isolation data for the serial segments of each twig were compiled to determine the distance of fungal growth in the twig from the inoculation point. Trees were rated independently by two observers for severity of gum exudation on a 0 to 3 scale $(0=$ no gum present, 1 = slight gum exudation from trunk, 2 = moderate gum exudation from trunk and possibly a few scaffold limb cank-

Table 1. Three measurements of disease severity 8 months after inoculation of twigs on 10-year-old trees near Fort Valley, Ga., with Botryosphaeria spp. (1983).

\begin{tabular}{|c|c|c|c|c|c|c|}
\hline \multirow[b]{2}{*}{ Cultivar } & \multirow{2}{*}{$\begin{array}{c}\text { Invasion } \\
\text { distal to } \\
\text { inoculation } \\
(\mathrm{mm}) \\
\end{array}$} & \multirow{2}{*}{$\begin{array}{l}\text { Invasion } \\
\text { proximal to } \\
\text { inoculation } \\
\text { (mm) }\end{array}$} & \multicolumn{3}{|c|}{ Vascular discoloration $^{z}$} & \multirow{2}{*}{$\begin{array}{c}\text { Mean } \\
\text { gum } \\
\text { rating }\end{array}$} \\
\hline & & & $\begin{array}{l}\text { Distal } \\
(\mathrm{mm})\end{array}$ & $\begin{array}{c}\text { Proximal } \\
(\mathrm{mm})\end{array}$ & $\begin{array}{l}\text { Total } \\
(\mathrm{mm})\end{array}$ & \\
\hline $\begin{array}{l}\text { Harbrite } \\
\text { Harken } \\
\text { Winblo } \\
\end{array}$ & $\begin{array}{l}20 \mathrm{a} \\
20 \mathrm{a} \\
20 \mathrm{a} \\
\end{array}$ & $\begin{array}{l}28 \mathrm{a} \\
28 \mathrm{a} \\
31 \mathrm{a}\end{array}$ & $\begin{array}{l}38 \mathrm{~b} \\
38 \mathrm{~b} \\
48 \mathrm{a}\end{array}$ & $\begin{array}{l}55 \mathrm{~b} \\
58 \mathrm{ab} \\
66 \mathrm{a}\end{array}$ & $\begin{array}{r}92 \mathrm{~b} \\
95 \mathrm{~b} \\
114 \mathrm{a}\end{array}$ & $\begin{array}{l}1.6 \mathrm{~b} \\
1.8 \mathrm{~b} \\
2.6 \mathrm{a}\end{array}$ \\
\hline
\end{tabular}

${ }^{2}$ Data for the threc Botryosphaeria spp. were pooled, so each value is the mean of 360 inoculations. Means in columns followed by the same letter are not significantly different at $P<0.05$. 'Mean of two independent ratings of gum from natural infections of 12 trees for each cultivar. Scale: $0=$ no gum present, 1 = some gum exuding from trunk, 2 = moderate gumming on trunk with some scaffold limbs infected, 3 = heavy gumming on trunk and scaffold limbs. 
ers, 3 = heavy gumming from trunk and scaffold limbs). Means for both observers ranked cultivars identically; therefore, only the grand means are presented here. A $\chi^{2}$ test of independence of association was used to compare the response of the trees following inoculation with each species of Botryosphaeria. No significant differences $(P=$ 0.05 ) due to fungal species were found;

Table 2. Vascular discoloration, fungal invasion, and gum ratings 5 months after inoculation of peach trees at Byron, Ga. (1983).

\begin{tabular}{lccc}
\hline \hline & $\begin{array}{c}\text { Vascular } \\
\text { discoloration } \\
\text { distance } \\
\text { (mm) }\end{array}$ & $\begin{array}{c}\text { Fungal } \\
\text { invasion } \\
\text { distance } \\
\text { (mm) }\end{array}$ & $\begin{array}{c}\text { Total gum } \\
\text { ratings }\end{array}$ \\
selection or & $\begin{array}{c}\text { Inoculated with } \mathrm{B} \text {. obtusa } \\
\text { }\end{array}$ \\
Summergold & $155 \mathrm{~b}$ & $20 \mathrm{ab}$ & $22 \mathrm{a}$ \\
Loring & $132 \mathrm{~b}$ & $8 \mathrm{~b}$ & $20 \mathrm{ab}$ \\
PI-101686 & $132 \mathrm{~b}$ & $43 \mathrm{ab}$ & $16 \mathrm{bc}$ \\
PI-43289 & $145 \mathrm{~b}$ & $56 \mathrm{ab}$ & $10 \mathrm{~d}$ \\
Harbrite & $259 \mathrm{a}$ & $91 \mathrm{a}$ & $14 \mathrm{~cd}$ \\
\multicolumn{5}{c}{ Inoculated with B. dothidea } \\
Summergold & $99 \mathrm{ab}$ & $0 \mathrm{a}$ & $22 \mathrm{a}$ \\
Loring & $150 \mathrm{a}$ & $0 \mathrm{a}$ & $19 \mathrm{ab}$ \\
PI-101686 & $142 \mathrm{a}$ & $11 \mathrm{a}$ & $15 \mathrm{bc}$ \\
PI-43289 & $135 \mathrm{a}$ & $1 \mathrm{a}$ & $10 \mathrm{~cd}$ \\
Harbrite & $53 \mathrm{~b}$ & $0 \mathrm{a}$ & $7 \mathrm{~d}$ \\
\multicolumn{5}{c}{ Inoculated with B. rhodina } \\
Summergold & $185 \mathrm{ab}$ & $13 \mathrm{~b}$ & $33 \mathrm{a}$ \\
Loring & $168 \mathrm{~b}$ & $35 \mathrm{~b}$ & $33 \mathrm{a}$ \\
PI-101686 & $231 \mathrm{a}$ & $61 \mathrm{ab}$ & $22 \mathrm{~b}$ \\
PI-43289 & $170 \mathrm{ab}$ & $86 \mathrm{a}$ & $21 \mathrm{~b}$ \\
\hline
\end{tabular}

${ }^{2}$ Expressed as mean distance above and below the inoculation point for 12 twigs. Mean separation by Duncan's multiple range test $(P=0.05)$ is for cultivars within each fungal inoculant group. Total of 10 gum ratings ( 0 to 4 scale) taken 2 June, 23 June, 19 July, 16 Aug., and 19 Sept.

Table 3. Vascular discoloration, fungal inva-sion, and gum ratings of branches of cultivars inoculated with $B$. dothidea at Byron, Ga. (1986). ${ }^{2}$

\begin{tabular}{|c|c|c|c|}
\hline $\begin{array}{l}\text { Cultivar or } \\
\text { selection }\end{array}$ & $\begin{array}{c}\text { Vascular } \\
\text { discoloration } \\
(\mathrm{mm})\end{array}$ & $\begin{array}{c}\text { Fungal } \\
\text { invasion } \\
\text { distance } \\
\text { from inocu- } \\
\text { lation } \\
\text { (mm) } \\
\end{array}$ & $\begin{array}{c}\text { Total } \\
\text { gum } \\
\text { ratings }\end{array}$ \\
\hline $\begin{array}{l}\text { Loring } \\
\text { PI-101686 } \\
\text { PI-43289 } \\
\text { Harbrite } \\
\text { Redglobe } \\
\text { Winblo }\end{array}$ & $\begin{array}{l}83 \\
99 \\
86 \\
56 \\
68 \\
84\end{array}$ & $\begin{array}{l}51 \\
53 \\
51 \\
53 \\
46 \\
43\end{array}$ & $\begin{array}{c}10 a b \\
13 a \\
4 c \\
10 a b \\
11 a b \\
9 b\end{array}$ \\
\hline
\end{tabular}

2Data shown are means of 16 observations. therefore, the data for all fungi were pooled. 'Harbrite' and 'Harken' produced significantly less gum and vascular discoloration than 'Winblo' (Table 1). There were no differences between 'Harbrite' and 'Harken'. Discoloration and fungal invasion were more extensive below the inoculation point than in the distal portion of the twig. There were no significant differences in the extent of fungal colonization among the cultivars.

Gum ratings as indicators of vascular discolor: field inoculation (Expt. 2). To determine if gum ratings were reliable indicators of fungal colonization rates and vascular discoloration, three trees each of 'Summergold', 'Loring', PI-101686, PI-43289, and 'Harbrite' were inoculated on 23 May 1983 in an orchard at the USDA Fruit and Tree Nut Laboratory, Byron, Ga. Four 1- to 2year-old twigs on each tree were wounded by squeezing lightly with pliers and then painted with $10^{5}$ conidia/ml. Ratings of gum exudation from these wounds were made on 2 and 23 June, 19 July, 16 Aug., and 15 Sept. Twigs were removed 4 Oct. for vascular discoloration measurement and fungal re-isolation as in the first experiment. Very poor re-isolation of $B$. dothidea was obtained in this experiment; therefore, field inoculations with this species were repeated on most of these cultivars in 1986.

Cultivar rankings for gum production were similar for all three Botryosphaeria spp. 'Summergold' and 'Loring' produced significantly more gum than PI-43289 or 'Harbrite' (Table 2). B. rhodina induced more gum and vascular discoloration than the other two species.

Cultivar ranking for vascular discoloration varied among the three fungi. 'Harbrite' was severely discolored following inoculation with B. obtusa, yet it exhibited the least discoloration when inoculated with $B$. dothidea. This cultivar was not inoculated with $B$. rhodina due to lack of trees. PI-43289 had minimal discoloration when inoculated with $B$. rhodina or B. obtusa, yet this selection was among those most extensively discolored following inoculation with $B$. dothidea.

Fungal re-isolation data provided concurring rank orders for the cultivars inoculated with B. obtusa and B. rhodina. 'Harbrite' was most successfully colonized by $B . o b$ tusa. PI-43289 and PI-101686 were next in rank order for both B. obtusa and B. rhodina. 'Loring' and 'Summergold' were least

Table 4. Response of 'Blake' peach to inoculation with Botryosphaeria spp. under greenhouse conditions.

\begin{tabular}{lccccc}
\hline \hline Botryospheria & $\begin{array}{c}\text { Dye uptake } \\
(\mathrm{cm} / 10 \mathrm{sec})\end{array}$ & $\begin{array}{c}\text { External } \\
\text { necrosis } \\
\text { length } \\
(\mathrm{mm})\end{array}$ & $\begin{array}{c}\text { Vascular } \\
\text { discoloration } \\
(\mathrm{mm})\end{array}$ & $\begin{array}{c}\text { Induced } \\
\text { gum }^{\mathbf{y}}\end{array}$ & $\begin{array}{c}\text { Fungal }^{\mathbf{x}} \\
\text { invasion } \\
\text { distance } \\
(\mathrm{mm})\end{array}$ \\
\hline Control & $10.3 \mathrm{a}$ & $1 \mathrm{~b}$ & $6 \mathrm{~b}$ & $11 \mathrm{~b}$ & $0 \mathrm{c}$ \\
B. dothidea & $9.0 \mathrm{ab}$ & $12 \mathrm{ab}$ & $14 \mathrm{~b}$ & $59 \mathrm{~b}$ & $47 \mathrm{~b}$ \\
B. obtusa & $10.2 \mathrm{a}$ & $4 \mathrm{ab}$ & $27 \mathrm{a}$ & $12 \mathrm{~b}$ & $29 \mathrm{~b}$ \\
B. rhodina & $7.9 \mathrm{~b}$ & $21 \mathrm{a}$ & $33 \mathrm{a}$ & $746 \mathrm{a}$ & $74 \mathrm{a}$ \\
\hline
\end{tabular}

${ }^{2}$ Means in columns followed by the same letter are not significantly different at $P=0.05$, according to Duncan's multiple range test. Data shown are means of seven observations.

'Data represent means of 15 observations.

${ }^{x}$ Mean re-isolation distance from inoculation point. Data shown are means of eight observations. colonized by these fungi; these cultivars also had the highest rankings for gum exudation. The cultivars or selections most extensively invaded, 'Harbrite', PI-43289, and PI101686, were those least prone to gumming.

Re-isolation rates for $B$. dothidea were too low to provide any estimation of the relative colonization rates. Inoculations with this species were repeated in 1986 (Table 3). Despite a satisfactory fungal re-isolation frequency, no significant differences were found among cultivars in either the invasion rate or the extent of vascular discoloration. Gum ratings were highest for PI-101686 and lowest for PI-43982.

Gum ratings: greenhouse inoculations. One-year-old 'Blake' trees on Lovell rootstock were inoculated to evaluate the predictive value of gum ratings as an indicator of disease severity. Postinoculation increase in caliper (PIC) was chosen as the most meaningful measurement of disease impact. Tree diameter was measured $10 \mathrm{~cm}$ above the graft union both 1 month and 1 day before inoculation; the growth rate obtained was used to estimate individual tree vigor. Sixty trees were wounded $6 \mathrm{~cm}$ above the graft with a 4-mm-diameter cork borer. The bark plug was replaced with agar-bearing mycelium from 5-day-old cultures of $B$. obtusa, $B$. dothidea, B. rhodina, or uninoculated APDA. Inoculation sites were wrapped with parafilm strips. Length of the necrotic lesion, weight of the gum exudate, and PIC were determined after 9 weeks. In each treatment, eight trees were cut in serial $1-\mathrm{cm} \mathrm{sec-}$ tions, examined for vascular discoloration, and plated on APDA to determine the extent of Botryosphaeria colonization within the tree. The other seven trees were used to measure xylem dysfunction. These were severed $3 \mathrm{~cm}$ below the inoculation point, and the trunk section cut to a total length of $20 \mathrm{~cm}$. The lower end was immediately immersed in a small beaker containing $2 \%$ aqueous safranin. After 10 see, the stem was removed and dissected to locate the leading edge of dye in the xylem.

All the severity measurements yielded consistent rankings (Table 4). Xylem dysfunction, external necrosis, vascular discoloration, gum exudation, and fungal colonization were most severe on trees inoculated with $B$. rhodina, although the differences between it and one or both of the other species were not always significant (Table 4).

The correlation matrix showed that, when a single cultivar was inoculated with the three species of Botryosphaeria, the weight of gum produced was significantly correlated with the extent of necrosis visible externally, with vascular discoloration, and with fungal invasion (Table 5). However, the only measurement significantly correlated with PIC was growth of the tree before inoculation.

In field tests comparing the response of different cultivars to inoculation, each of the severity measures gave a different cultivar ranking. These same measures yielded consistent rank ordering of fungal species for aggressiveness in greenhouse inoculations of 
Table 5. Pearson correlation coefficients and the probability that $\rho=0$ (in parentheses) from greenhouse inoculation of 'Blake' peach with three species of Botryosphaera.

\begin{tabular}{|c|c|c|c|c|c|c|}
\hline $\begin{array}{l}\text { Dependent } \\
\text { variable }\end{array}$ & $\begin{array}{l}\text { External } \\
\text { necrosis }\end{array}$ & $\begin{array}{c}\text { Vascular } \\
\text { discoloration }\end{array}$ & $\begin{array}{c}\text { Fungal } \\
\text { invasion }\end{array}$ & $\begin{array}{c}\text { Dye } \\
\text { uptake }\end{array}$ & $\begin{array}{c}\text { Growth before } \\
\text { inoculation }\end{array}$ & $\begin{array}{c}\text { Growth after } \\
\text { inoculation }\end{array}$ \\
\hline Gum & & & & & & \\
\hline weight & $\begin{array}{c}0.768 \\
(0.0001)\end{array}$ & $\begin{array}{c}0.579 \\
(0.0002)\end{array}$ & $\begin{array}{c}0.361 \\
(0.03)\end{array}$ & $\begin{array}{r}0.139 \\
(0.62)\end{array}$ & $\begin{array}{r}0.129 \\
(0.36)\end{array}$ & $\begin{array}{r}0.044 \\
(0.76)\end{array}$ \\
\hline $\begin{array}{l}\text { External } \\
\text { necrosis }\end{array}$ & & $\begin{array}{c}0.541 \\
(0.0005)\end{array}$ & $\begin{array}{c}0.100 \\
(0.56)\end{array}$ & $\begin{array}{r}0.113 \\
(0.67)\end{array}$ & $\begin{array}{l}0.009 \\
(0.95)\end{array}$ & $\begin{array}{c}0.032 \\
(0.82)\end{array}$ \\
\hline $\begin{array}{l}\text { Vascular } \\
\text { discoloration }\end{array}$ & & & $\begin{array}{c}0.620 \\
(0.0001)\end{array}$ & & $\begin{array}{r}0.159 \\
(0.34)\end{array}$ & $\begin{array}{r}0.215 \\
(0.19)\end{array}$ \\
\hline $\begin{array}{l}\text { Fungal } \\
\text { invasion }\end{array}$ & & : & & & $\begin{array}{r}0.161 \\
(0.33)\end{array}$ & $\begin{array}{r}0.100 \\
(0.55)\end{array}$ \\
\hline $\begin{array}{l}\text { Dye } \\
\text { uptake }\end{array}$ & & & & & $\begin{array}{c}0.142 \\
(0.60)\end{array}$ & $\begin{array}{c}0.366 \\
(0.13)\end{array}$ \\
\hline $\begin{array}{l}\text { Growth before } \\
\text { inoculation }\end{array}$ & & & & & & $\begin{array}{c}0.346 \\
(0.01)\end{array}$ \\
\hline
\end{tabular}

'Blake'. Uniform conditions provided in greenhouse studies may be partially responsible for improved reliability of these measurements. Another possible explanation is that the three species of Botryosphaeria are less diverse genetically than are peach cultivars. Differences in vigor among the cultivars and selections under specific field conditions, rather than specific induced responses to infection, may play a major role in determining resistance to PTFG.

Wound susceptibility to invasion is influenced by any factor affecting the wound reponse, e.g., season, drought, temperature stress, or soil fertility (Biggs et al., 1984). The effects of various stresses on the rate of necrophyllactic periderm formation may interact significantly among cultivars, changing the rank order of susceptibility. Biggs and Cline (1986) found that suberin accumulation in wounded 'Candor' trees was enhanced by irrigation, while the wound response of 'Redhaven' was not stimulated. The rank order of cultivars for suberin ac- cumulation correlates with susceptibility to Cytospora canker, when suberin deposition is measured in May or June, but not if measured in July or August (Biggs, 1987). Thus, relative susceptibility of cultivars may vary with experimental conditions, and with growers' management practices, since optimum growing conditions can reduce the detrimental effects of facultative parasites such as Botryosphaeria spp. (Schoeneweiss, 1981).

'The biological significance of induced responses must be determined before they can be safely interpreted as accurate predictors of disease impact. Copious gum exudation represents a loss of carbohydrates that probably causes some loss in fruit yield or quality, as well as tree vigor. In addition, gum physically plugs the xylem vessel elements (Hampson and Sinclair, 1973). These energy costs in cultivars prone to gumming may be more detrimental than the parasitic activities of the fungi, especially if trees encounter stress. In view of the present lack of understanding of the relative energy costs of gum production and of compartmentalizing infection vs. toleration of parasitism in woody hosts, it seems advisable to use as many measurements as possible to assess cultivar resistance, and examine these in the light of long-term tree productivity.

\section{Literature Cited}

Biggs, A.R. 1987. Use of wound response parameters to assess relative susceptibility of peach cultivars toLeucostoma spp. Phytopathology 77:1690.

Biggs, A.R. and R.A. Cline. 1986. Influence of irrigation on wound response in peach bark. Can. J. Plant Pathol. 8:405-408.

Biggs, A.R., W. Merrill, and D.D. Davis. 1984. Discussion: Response of bark tissues to injury and infection. Can. J. For. Res. 14:351-356.

Britton, K.O. and F.F. Hendrix. 1982. Three species of Botryosphaeria cause peach tree gummosis in Georgia. Plant Dis. 66:1120-1121.

Britton, K.O. and F.F. Hendrix. 1984. Studies toward the biology and control of peach tree gummosis. Proc. 2nd Stone Fruit Decline Wkshp. Kearneysville, W.Va.

Daniell, J.W. and W.A. Chandler. 1982. Field resistance of peach cultivars to gummosis disease. HortScience 17:375-376.

Hampson, M.C. and W. A. Sinclair. 1973. Xylem dysfunction in peach caused by Cytospora leucostoma. Phytopathology 63:676-680.

Okie, W.R. and C.C. Reilly. 1983. Reaction of peach and nectarine cultivars and selections to infection by Botryosphaeria dothidea. J. Amer. Soc. Hort. Sci. 108:176-179.

Reilly, C.C. and W.R. Okie. 1982. Distribution in the Southeastern United States of peach tree fungal gummosis caused by Botryosphaeria dothidea. Plant Dis. 66:158-161.

Schoeneweiss, D.F. 1981. The role of environmental stress in diseases of woody plants. Plant Dis. 65:308-314.

Weaver, D.J. 1974. A gummosis disease of peach trees caused by Botryosphaeria dothidea. Phytopathology 64:1429-1432.

Willison, R.S. 1932. Wound gum in peaches and grapes. Its relation to the invasion of fungus wound-parasites. Sci. Agr. 12:402-419, 484505 . 